\title{
Monitoring active fault creep as a tool in seismic hazard mitigation. Insights from creepmeter study at Chihshang, Taiwan
}

\author{
Jian-Cheng Lee ${ }^{\mathrm{a}, *}$, Jacques Angelier ${ }^{\mathrm{b}, \mathrm{c}}$, Hao-Tsu Chu ${ }^{\mathrm{d}}$, Jyr-Ching $\mathrm{Hu}^{\mathrm{e}}$, Fu-Shu Jeng ${ }^{\mathrm{f}}$ \\ ${ }^{a}$ Institute of Earth Sciences, Academia Sinica, P.O. Box 1-55, Nankang, Taipei, R.O.C., Taiwan \\ ${ }^{\mathrm{b}}$ Observatoire océanologique de Villefranche, Géosciences Azur, B.P. 48, 06235 Villefranche-sur-Mer, France \\ ${ }^{\mathrm{c}}$ Institut universitaire de France, 103, bd Saint-Michel, 75005 Paris, France \\ d Central Geological Survey, P.O. Box 968, Taipei, R.O.C., Taiwan \\ e Department of Geosciences, National Taiwan University, Taipei, R.O.C., Taiwan \\ ${ }^{\mathrm{f}}$ Department of Civil Engineering, National Taiwan University, Taipei, R.O.C., Taiwan
}

Received 8 April 2004; accepted after revision 18 April 2005

Available online 2 August 2005

Written on invitation of the Editorial Board

\begin{abstract}
In 1998 we installed five creepmeters across the Chihshang Fault, the active plate suture in eastern Taiwan. Daily creepmeter data indicated decreasing creeping rate from 1999 to 2003, suggesting increasing seismic hazard. The fault was ruptured by the Chengkung earthquake $(M w=6.6)$ on 10 December 2003. Through extrapolation of our earlier creep data of 1986-1991 and 1992-1997, we evaluate the minimum deficit in aseismic creep shortening as 106 or $46 \mathrm{~mm}$ (respectively) before this earthquake. The near-surface co-seismic shortening was limited, but the total shortening resulting from the earthquake, including post-seismic creep, was about $97 \mathrm{~mm}$. This suggests that near the surface most of the detectable deficit has been absorbed by this earthquake and subsequent creep. We thus point out that creepmeter installation and monitoring bring a powerful tool in seismic hazard mitigation. To cite this article: J.-C. Lee et al., C. R. Geoscience 337 (2005).
\end{abstract}

๑ 2005 Académie des sciences. Published by Elsevier SAS. All rights reserved.

\section{Résumé}

La surveillance du glissement asismique d'une faille active, outil de prévision sismique. Apport d'une étude extensométrique à Chihshang, Taiwan. En 1998, nous avons installé des extensomètres sur la faille de Chihshang, à la suture active de plaques dans l'Est de Taiwan. Nos données de 1999 à 2003 indiquaient une diminution du mouvement depuis l'an 2000, donc un risque sismique croissant. La faille de Chihshang a été réactivée le 10 décembre 2003 par le séisme de Chengkung $(M w=6,6)$. En extrapolant nos données de glissement de 1986-1991 ou 1992-1997, nous estimons le déficit minimum de raccourcissement par glissement asismique à 106 ou $46 \mathrm{~mm}$ (respectivement) avant ce séisme. Le jeu co-sismique a été modéré, mais le mouvement total associé au séisme de Chengkung, y compris le glissement post-sismique, a atteint 97 mm environ. Nous en déduisons que, près de la surface, la plus grande partie du déficit détectable a été absorbée par ce séisme et par le

\footnotetext{
* Corresponding author.

E-mail address: jclee@earth.sinica.edu.tw (J.-C. Lee).
} 
glissement post-sismique immédiat. Nous soulignons ainsi l'importance d'une installation et d'un suivi d'extensomètres à des fins d'analyse du risque sismique. Pour citer cet article : J.-C. Lee et al., C. R. Geoscience 337 (2005).

(C) 2005 Académie des sciences. Published by Elsevier SAS. All rights reserved.

Keywords: Active fault; Creep; Earthquake; Strain; Seismic cycle; Seismic hazard; Taiwan

Mots-clés : Faille active; Glissement ; Séisme ; Déformation ; Cycle sismique ; Risque sismique ; Taiwan

\section{Version française abrégée}

\section{Introduction}

Le cycle sismique d'une faille active peut faire alterner rupture co-sismique et glissement inter-sismique [13]. La déformation peut être accumulée pendant la période inter-sismique, puis relâchée lors d'un séisme important. Une part de la déformation peut aussi être relâchée par glissement sur la faille durant la période inter-sismique. La compréhension de ces phénomènes est essentielle pour l'étude du risque sismique. Nous décrivons dans cette note la mesure du glissement sur une faille active, à des fins d'évaluation du risque sismique.

La faille de Chihshang est un segment long de $20 \mathrm{~km}$ de la faille de la Vallée longitudinale (Fig. 1), une suture majeure à Taiwan $[3,6,14]$. La convergence des plaques, $85 \mathrm{~mm} \mathrm{an}^{-1}$ [15], y est absorbée pour environ $25-35 \%$, soit $20-30 \mathrm{~mm} \mathrm{an}^{-1}$ [16]. Sur la zone de faille de Chihshang s'est produit un raccourcissement de 20-25 $\mathrm{mm} \mathrm{an}^{-1}$ par glissement lent pendant les derniers 20 ans $[9,17]$, dont $22 \mathrm{~mm} \mathrm{an}^{-1}$ sur une seule faille $[1,2]$.

En 1998, nous avons installé des extensomètres sur la faille de Chihshang afin de contraindre l'évolution du glissement en plus grand détail qu'auparavant $[1,2,10-12]$. Nos données indiquent une diminution du mouvement depuis l'an 2000, indiquant un risque sismique croissant sur la faille de Chihshang. Le séisme de Chengkung (10 décembre 2003, $M w=6,6$ ) a activé cette faille. Nous présentons donc les données de glissement depuis 1998, et nous nous efforçons d'en tirer les conclusions en termes de variation du risque sismique.

\section{La faille de Chihshang}

La faille de Chihshang, NNE-SSW, est le chevauchement principal de la chaîne côtière sur la Vallée longitudinale et la chaîne centrale de Taiwan (Fig. 1). Elle a été réactivée en 1951pendant le séisme de Yuli $(M s=7,1)$, à l'origine de ruptures de surface notables [4,7]. Pendant les 20 dernières années au moins, la faille de Chihshang a été le siège d'un glissement soutenu $[9,17]$, également à l'origine de multiples fractures $[1,2,5,8]$.

Les mesures du déplacement de la faille de Chihshang résultent de triangulations à travers la vallée $[16,17]$, mesures de terrain [1,2], triangulations et nivellements locaux $[1,2,9]$ et usage d'extensomètres [10,11]. De 1986 à 1997, le taux de raccourcissement a été assez stable, mais à tendance décroissante, 22-27 $\mathrm{mm} \mathrm{an}^{-1}$. La faille est inverse-sénestre, avec des composantes verticale de $20 \mathrm{~mm} \mathrm{an}^{-1}$, horizontale transverse de $18 \mathrm{~mm} \mathrm{an}^{-1}$ et sénestre de $12 \mathrm{~mm} \mathrm{an}^{-1}$, indiquant un raccourcissement horizontal $\mathrm{N}^{\circ} 5^{\circ} \mathrm{W}$ de $22 \mathrm{~mm} \mathrm{an}^{-1}[1,2,8,9]$.

Nous avons installé des extensomètres sur les ruptures actives de la faille de Chihshang [10]. Les données, recueillies quotidiennement, révèlent un mouvement rapide pendant la saison humide et lent voire nul pendant la saison sèche [11], ce qui témoigne d'un effet saisonnier dans les couches superficielles. Le glissement s'est ralenti de 22 à $14 \mathrm{~mm} \mathrm{an}^{-1}$ pendant la période 2000-2003, suggérant un risque sismique accru. Le séisme de Chengkung $(M w=6,6)$ a d'ailleurs remobilisé la faille de Chihshang en décembre 2003, montrant la pertinence de ce type d'analyse pour l'évaluation du risque sismique.

\section{Instrumentation et calibrage thermique}

Nos cinq extensomètres sur la faille de Chihshang ont été installés à Tapo et Chinyuan (Fig. 1). Un modèle résistant a été inventé [10], avec des ancrages des deux côtés de la faille active (Fig. 2). L'instrument comprend deux barres parallèles en Invar, dont le mouvement relatif est enregistré par une jauge de déplacement. Les mesures ont été quotidiennes. 
Le calibrage thermique a été effectué sur place, pour chaque appareil et pour deux échelles de temps. Les changements journaliers de température induisent une variation de longueur de $0,4-0,8 \mathrm{~mm}$ pour un contraste typique de $13-15^{\circ} \mathrm{C}$. Les changements saisonniers induisent une variation de longueur de 2,0 $2,2 \mathrm{~mm}$. pour un contraste typique moyen de $17^{\circ} \mathrm{C}$ entre hiver et été. Nous avons déterminé les coefficients thermo-élastiques pour chaque extensomètre, et ainsi pu effectuer les corrections. Les enregistrements, habituellement faits avant le crépuscule, comprennent heure, température et raccourcissement.

\section{Les données de glissement de 1998 à 2004}

Nous présentons ici les données obtenues avec les trois extensomètres de Chinyuan d'août 1998 à décembre 2004. Ces extensomètres (3, 4 et 5 , d'ouest en est) ont été installés sur trois failles parallèles; leur orientation est proche de celle du mouvement. Ils fournissent donc une mesure presque directe du déplacement relatif. Les données de glissement sont fournies sous forme de raccourcissement (en $\mathrm{mm}$ ) en fonction du temps (Fig. 3 et Tableau 1). A cause du mouvement brutal de la faille de Chihshang lors du séisme de Chengkung du 10 décembre 2003 (Fig. 3), le glissement annuel pour l'année 2003 est arrêté au 9 décembre au lieu du 31. Toutefois, le raccourcissement total découlant de ce séisme inclut la déformation rapide qui l'a suivi, jusqu'en décembre 2004.

Tous les extensomètres ont enregistré un glissement rapide pendant la saison humide et peu de mouvement pendant la saison sèche, particulièrement en décembre et janvier (Fig. 3). Les variations temporelles du mouvement se sont révélées homothétiques pour les trois sites depuis la mise en service de 1998 , les proportions étant de 34,18 et $48 \%$ pour les extensomètres 3,4 et 5 (respectivement). La raccourcissement total a atteint 73,5 mm du $1^{\text {er }}$ janvier 1999 au 9 décembre 2003, soit une moyenne de $15 \mathrm{~mm} \mathrm{an}^{-1}$.

\section{Implications en matière de risque sismique et conclusions}

Les relevés de la période 1990-1997 avaient mis en évidence une vitesse de glissement assez stable de $27 \mathrm{~mm} \mathrm{an}^{-1}$ pour $1986-1992$ et de $22 \mathrm{~mm} \mathrm{an}^{-1}$ pour 1992-1997 [1,2], à comparer aux $18 \mathrm{~mm} \mathrm{an}^{-1}$ de 1999. Nos nouvelles données d'extensomètres de la période 1999-2003 (Tableau 1 et Fig. 3) révèlent une forte décroissance de la vitesse de glissement avant le séisme de Chengkung en décembre 2003. Prenant pour référence le raccourcissement de $18 \mathrm{~mm}$ de 1999 , le déficit de raccourcissement a été de $4 \mathrm{~mm}$ en 2000 , $5,5 \mathrm{~mm}$ en $2001,4 \mathrm{~mm}$ en 2002 et $3 \mathrm{~mm}$ en 2003 (22, 30,5, 22 et $16,7 \%$, respectivement), soit $16,5 \mathrm{~mm}$ de déficit jusqu'au séisme de Changkung en 2003. Par rapport à la vitesse de glissement moyenne de la période 1992-1997 (22 $\left.\mathrm{mm} \mathrm{an}^{-1}\right)$, la diminution est plus forte (au moins 18,2\% en 1999, 36,4\% en 2000, $43,2 \%$ en $2001,36,4 \%$ en 2002 et $31,8 \%$ en 2003 ) et le déficit est de $46 \mathrm{~mm}$. Par rapport à la vitesse moyenne de 1996-1992 (27 $\left.\mathrm{mm} \mathrm{an}^{-1}\right)$, ce déficit atteint $106 \mathrm{~mm}$. Nous interprétons ce ralentissement du glissement en 2000-2003 comme la marque d'une accumulation de déformation compressive précédant le séisme de Chengkung.

Les extensomètres implantés sur la faille de Chihshang en 1998 nous permettent de connaître en détail l'évolution du glissement en surface. Nos données mettent en évidence une décroissance significative de la vitesse de glissement au cours des 5,5 années qui ont précédé le séisme de Chengkung de 2003. La prise en compte des résultats de la période 1990-1997 [1,2] renforce cette conclusion en révélant un fort ralentissement du glissement, de $22 \mathrm{~mm} \mathrm{an}^{-1}$ en 1990-1997 à $14 \mathrm{~mm} \mathrm{an}^{-1}$ en 2000-2003. Le déficit en raccourcissement de surface pour la période 2000-2003 est d'environ $23 \%$ en moyenne par comparaison avec 1999, et d'au moins $37 \%$ en moyenne par comparaison avec la période 1990-1997.

Comme la période de déficit de glissement a conduit au séisme de Chengkung en 2003, de magnitude $M w=6,6$, nous estimons qu'un déficit supérieur aurait conduit à un séisme de magnitude supérieure, tel le séisme de Yuli en $1951(M s=7,1)$. Par comparaison avec nos résultats antérieurs [1,2], le déficit de raccourcissement a atteint 46-106 $\mathrm{mm}$ au moment du séisme de Chengkung (Fig. 4). Nos toutes dernières mesures ont révélé un raccourcissement d'environ $97 \mathrm{~mm}$, principalement post-sismique, du 10 décembre 2003 au 31 décembre 2004. Ceci nous incite à adopter pour le déficit minimum avant séisme la valeur haute, $106 \mathrm{~mm}$, correspondant à environ 12 ans d'accumulation. Nous en déduisons qu'une grande partie du déficit détectable a été absorbée par le séisme de 
Chengkung et ses suites. Bien qu'il demeure difficile de tirer des conclusions certaines d'une observation sur moins de 20 ans, nous soulignons l'intérêt d'une installation et d'un suivi d'extensomètres dans un tel contexte sismotectonique, contribuant à la prise en compte du risque sismique.

\section{Introduction}

The earthquake cycle of an active fault may include co-seismic rupture and inter-seismic slip [13]. During the inter-seismic stage, usually ranging from a few hundreds to tens of thousands years, crustal tectonic strain may be silently accumulated. This strain is released by abrupt co-seismic rupturing in a relatively short time (seconds to months), causing seismic hazard. Part of strain may also be released during the inter-seismic period, especially along creeping active faults. A better understanding of the transient deformation of the strain accumulation-relaxation processes is crucial in seismic hazard mitigation. To provide such insights, we present the monitoring of an active fault, the Chihshang Fault in eastern Taiwan.

The Chihshang Fault is a 20-km long segment of the Longitudinal Valley Fault (Fig. 1), a major plate suture in eastern Taiwan $[3,6,14]$. About $25-35 \%$ of the total convergence rate in Taiwan, $85 \mathrm{~mm} \mathrm{yr}^{-1}$ [15], amounting to $20-30 \mathrm{~mm} \mathrm{yr}^{-1}$, occurs across the Longitudinal Valley [16]. The Chihshang Fault zone exhibited creeping behaviour with a shortening rate of $20-25 \mathrm{~mm} \mathrm{yr}^{-1}$ during the last 20 years $[9,17]$.

Five creepmeters installed in 1998 across the surface breaks of the Chihshang Fault constrained the creep history of the fault with more temporal accuracy than earlier measurements $[1,2,10-12]$. These dailyrecorded data reveal decreasing creeping rate since year 2000, consistent with other data measured twice a year, collectively suggesting increasing seismic hazard along the Chihshang Fault. The Chengkung earthquake (10 December 2003, $M w=6.6)$ ruptured the Chihshang Fault. In this paper, we present the creepmeter data since 1998, and we discuss the decreasing creeping rate of the Chihshang Fault before the earthquake. We also point out how important the monitoring of the creeping behaviour along the active fault is, as a tool in seismic hazard mitigation.
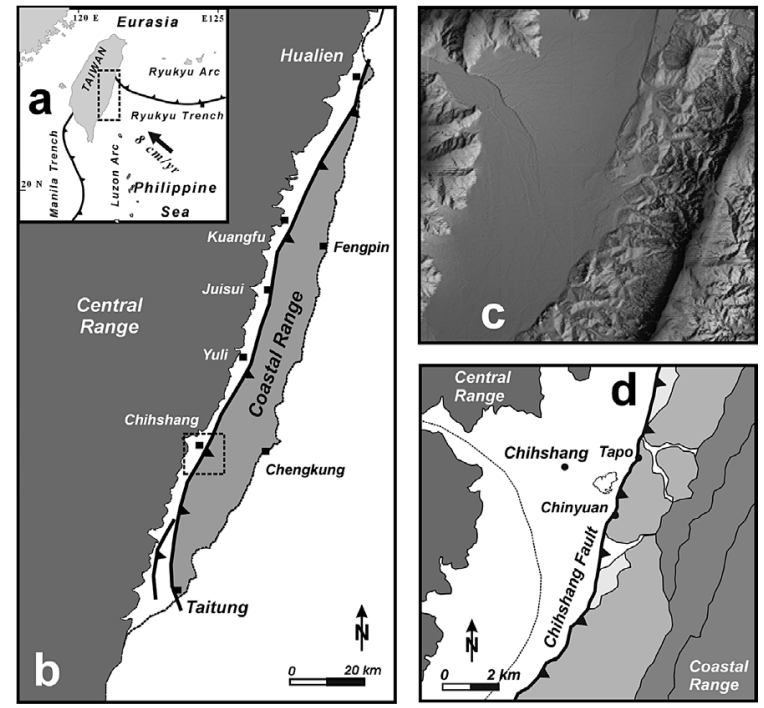

Fig. 1. (a) Tectonic setting of Taiwan (dashed frame: location of $\mathbf{b}$ ). (b) Map of the Longitudinal Valley suture zone (dashed frame: location of $\mathbf{c}$ and $\mathbf{d}$ ). Main thrust as thick line, triangles on upthrust side. (c) Shaded relief map of Chihshang area (location in b). (d) Geology of Chihshang area. Geological units of the Coastal Range: very light grey, Quaternary terraces; light grey, Pliocene Lichi Mélange; medium grey, Late Miocene of Luzon Arc and Plio-Quaternary Takangkou flysch. Chihshang Fault as thick line, triangles on the upthrust side.

Fig. 1. (a) Cadre tectonique de Taiwan (rectangle tireté : localisation de b). (b) Carte de la zone de suture de la Vallée Longitudinale (carré tireté : localisation de c et d). Chevauchement principal en trait gras, avec triangles du côté chevauchant. (c) Carte ombrée du relief de la région de Chihshang area (localisation : b). (d) Géologie de la région de Chihshang. Unités géologiques de la chaîne côtière : gris très clair, terrasses quaternaires; gris clair Mélange pliocène de Lichi; gris moyen, Miocène supérieur de l'arc de Luçon et flysch plio-quaternaire de Takangkou. Faille de Chihshang en trait gras, triangles du côté chevauchant.

\section{The Chihshang Fault}

The NNE-trending Chihshang Fault is the major fault along which the Coastal Range of the Miocene Luzon arc is thrust westwards over the Longitudinal Valley and the Central Range of Taiwan (Fig. 1). The Chihshang Fault ruptured during the 1951 Yuli earthquake $(M s=7.1)$, which produced surface breaks with scarps tens of centimetres high extending for tens of kilometres [4,7]. Later, the Chihshang Fault showed evidence of rapid creep at the surface, at least during the last 20 years $[9,17]$. Fault creep generated numer- 
ous surface breaks, mainly along the surface fault trace of the 1951 earthquake [1,2,5,8].

Measurements of displacement across the Chihshang Fault during the last 20 years cover a variety of temporal and spatial scales. They included across-valley trilateration and GPS surveys [16,17], field measurements of offsets [1,2], near-fault trilateration networks and levelling [1,2,9] and creepmeter monitoring [11,12]. The 1986-1997 results revealed a rather stable shortening rate, $22-27 \mathrm{~mm} \mathrm{yr}^{-1}$, with a decreasing trend, concentrating in a 30-150-m-wide fault zone. Kinematically, the 3-D surface creeping motion of the Chihshang Fault was characterised by oblique reverse faulting in the $\mathrm{N} 45^{\circ} \mathrm{W}$ direction, with a vertical component of $20 \mathrm{~mm} \mathrm{yr}^{-1}$, a transverse component of $18 \mathrm{~mm} \mathrm{yr}^{-1}$ and a left-lateral component of $12 \mathrm{~mm} \mathrm{yr}^{-1}[1,2,8,9]$, indicating $22 \mathrm{~mm} \mathrm{yr}^{-1}$ of horizontal shortening.

Since 1998, the creepmeter data collected on a daily basis [10] revealed a clear seasonal variation, with fast fault motion during the wet season and quiescence during the dry season, which implied close relation with rainfall [12]. However, the micro-seismic activity did not show this seasonal variation, suggesting decoupling between the shallow creeping zone and the 525-km-deep micro-earthquake-producing fault. Thus the seasonal variation was interpreted as an effect in the shallow level. All data, including the daily data of the creepmeters and the twice-a-year measurements of the on-site offsets and the near-fault geodetic networks, indicate a decreasing creeping rate from 22 to $14 \mathrm{~mm} \mathrm{yr}^{-1}$ during the 2000-2003 period, suggesting increasing seismic hazard along the Chihshang Fault. Indeed, the Chengkung earthquake $(M w=6.6)$ ruptured the Chihshang Fault in December 2003, showing that reliable expectation can be drawn from permanent creepmeter monitoring in terms of earthquake hazard mitigation.

\section{Instrumentation and thermal calibration}

We have installed five creepmeters across the Chihshang Fault at two sites, Tapo and Chinyuan (Fig. 1). A robust rod-type creepmeter was designed [12], with anchored piers on $60-\mathrm{cm} \times 60$-cm-wide concrete bases on opposite sides of the active fault (Fig. 2). On soil surface, a 0.5-m-deep cavity was dug for each pier and filled with pebbles, concrete, and
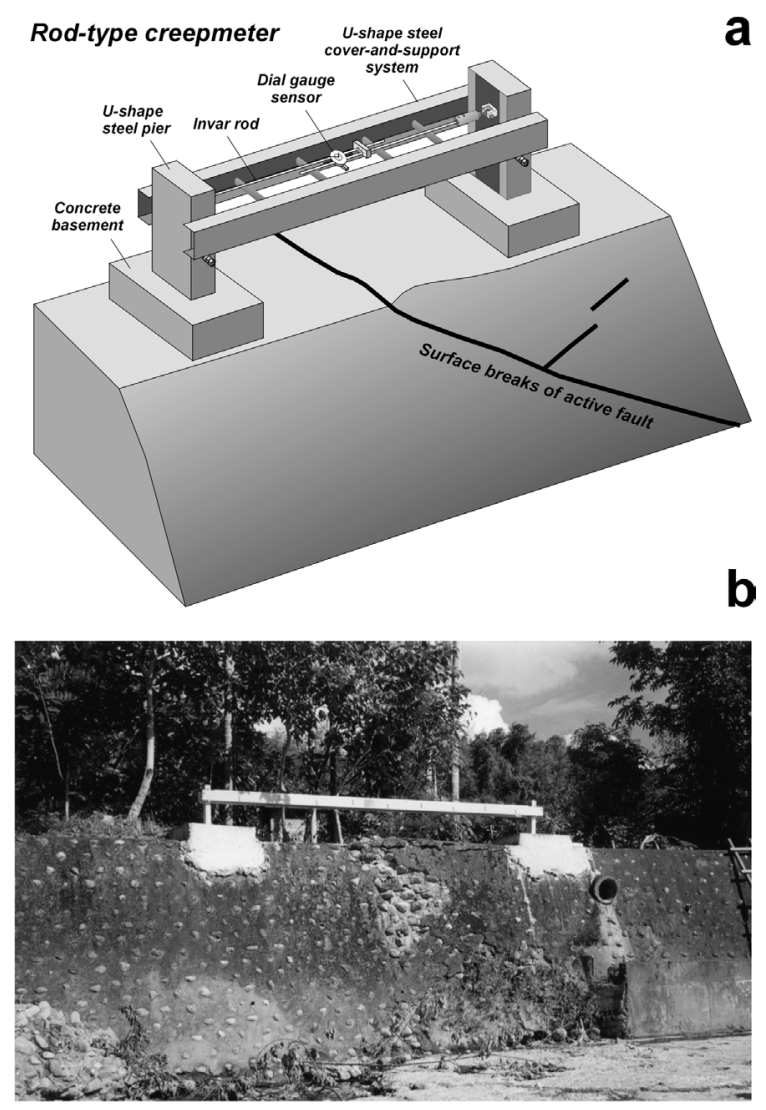

Fig. 2. (a) Schematic representation of our rod-type creepmeter [10] set up across an active fault rupturing a concrete wall. (b) Photograph of creepmeter 4 at Chinyuan.

Fig. 2. (a) Représentation schématique de notre extensomètre [10] installé sur une faille active affectant un mur en béton à la surface. (b) Vue de l'extensomètre 4 à Chinyuan.

iron bars implanted at more than 1-m depth, ensuring good coupling with the substratum. The instrument is composed of two parallel Invar rods, attached to each pier via universal connector and sustained by rollers fixed on a U-shaped steel support system. The relative movement of these Invar rods is measured with a mechanical dial-gauge sensor (resolution: $0.01 \mathrm{~mm}$, range: $50 \mathrm{~mm}$ ). The data were recorded once a day.

Despite the low thermal expansion coefficient of the Invar alloy rods, it was necessary to determine the thermal effect, which was not negligible. We carried out in-site temperature calibration, considering the thermal effect on both the Invar rods and the surrounding creepmeter structure. Although our creepmeters were identical, this calibration was done for each in- 
strument, considering possible differences in thermal effects at anchored pier level. The temperature effect was evaluated at two different time scales. The daily fluctuation causes a length variation of $0.4-0.8 \mathrm{~mm}$ for a typical difference of $13-15{ }^{\circ} \mathrm{C}$ between the lowest and the highest temperatures. The seasonal variation between the average lowest temperature in winter, $15^{\circ} \mathrm{C}$, and the average highest temperature in summer, $32^{\circ} \mathrm{C}$, causes a typical length variation of $2.0-2.2 \mathrm{~mm}$. The derived thermal-elastic coefficients for each creepmeter were taken as the basis of the temperature calibration and subsequent corrections. Reading and recording of data were usually done in the afternoon before sunset, including time, temperature and shortening data.

\section{Creep data, 1998-2004}

In this paper we focus on the data from three creepmeters at Chinyuan, obtained from August 1998 to December 2004 (at Tapo, shortening and gravitational effects interfere, which would require further discussion). The creepmeters (3, 4 and 5, from west to east) were set up across three individual previously identified fractures within a 120 m-wide deformation zone. The creepmeters trend nearly parallel to fault motion vector, so that the recorded shortening values are subequal to, or slightly less than, the actual surface shortenings of the faults. The creep data are presented as shortening (in mm) versus time (Fig. 3 and Table 1). Because the 10 December 2003 Chengkung earthquake produced quick surface displacement across the Chihshang Fault (Fig. 3), the annual shortening amount in 2003 is given until 9 December instead of 31 . Note that the total shortening resulting from the Chengkung earthquake includes that observed soon after the earthquake, until December 2004.

All creepmeters in Chinyuan showed seasonal variation, with fast creep in the wet season and quiescence in the dry season, especially December-January (Fig. 3). Temporal variations affected the three sites in the same manner. Thus, proportionality in shortening rates was approximately maintained since the beginning of operation in 1998, with 34,18 and $48 \%$ of motion being recorded by creepmeters 3,4 and 5 , re-

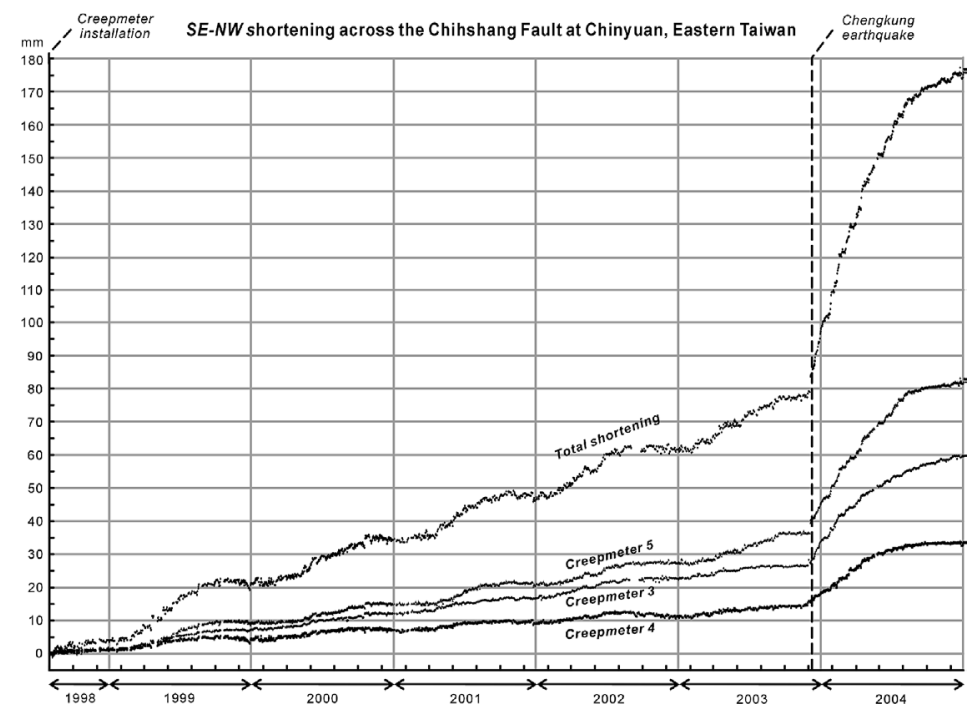

Fig. 3. Results of daily measurements on creepmeters at Chinyuan, from August 1998 to December 2004. Shortening (in millimetres) as a function of time. Creepmeters 3, 4 and 5 are located from west to east across three parallel surface breaks in the active fault zone. Note that the periods of rapid shortening in 1998-2003 correspond to the wet season. Significant after-slip creep shortening followed the 10 December $(M w=6.6)$ Chengkung earthquake, until mid-2004.

Fig. 3. Résultats des mesures journalières sur les extensomètres de Chinyuan, d'août 1998 à décembre 2004. Raccourcissement (en millimètres) en fonction du temps. Les extensomètres 3, 4 et 5 sont situés d'ouest en est sur trois branches parallèles de la zone de faille active. Noter que les périodes de raccourcissement rapide 1998-2003 correspondent à la saison humide. Un fort raccourcissement par glissement progressif a suivi le séisme de Chengkung du 10 décembre $2003(M w=6,6)$, jusqu'à la mi-2004. 
Table 1

Annual shortening amounts recorded by the three creepmeters at Chinyuan, from early 1999 to late 2003. Values in millimetres. Detail in the text. The 2003 shortening does not include data after 9 December, because of Chengkung earthquake. The shortening of the Chengkung earthquake sequence, co-seismic and post-seismic, is counted until December 2004

Tableau 1

Quantités de raccourcissement annuellement enregistrées par les trois extensomètres de Chinyuan, du début 1999 à la fin 2003 . Valeurs en millimètres. Détails dans le texte. Le raccourcissement de 2003 ne comprend pas les données postérieures au 9 décembre, en raison du séisme de Chengkung. Le raccourcissement de la séquence sismique de Chengkung (co- et post-sismique) est compté jusqu'en décembre 2004

\begin{tabular}{lcccccll}
\hline & 1999 & 2000 & 2001 & 2002 & 2003 & Total & Chengkung earthquake \\
\hline Creepmeter3 & 6 & 5 & 4.5 & 6 & 3.5 & 25 & 33 \\
Creepmeter4 & 4 & 3 & 2 & 2 & 2.5 & 13.5 & 19 \\
Creepmeter5 & 8 & 6 & 6 & 6 & 9 & 35 & 45 \\
Total & 18 & 14 & 12.5 & 14 & 15 & 73.5 & 97 \\
\hline
\end{tabular}

spectively. The total shortening before the Chengkung earthquake reached $73.5 \mathrm{~mm}$ from 1 January 1999 to 9 December 2003, that is, $15 \mathrm{~mm} \mathrm{yr}^{-1}$ on average.

\section{Implications for hazard evaluation and conclusions}

The surveys done during the period 1990-1997 had revealed a rather constant but decreasing slip velocity, $27 \mathrm{~mm} \mathrm{yr}^{-1}$ in $1986-1992$ and $22 \mathrm{~mm} \mathrm{yr}^{-1}$ in 1992-1997 [1,2], larger than, but still compatible with, the creepmeter data of $1999\left(18 \mathrm{~mm} \mathrm{yr}^{-1}\right)$. The new creepmeter data presented above for the period 19992003 (Table 1 and Fig. 3) thus reveal a quite significant decrease in creeping rate across the Chihshang Fault, until the Chengkung earthquake in December 2003 (characterised by an abrupt increase in shortening in all curves of Fig. 3). This decrease of creep rate in 2000-2003 is confirmed by other twice-a-year measurements, including fracture offsets measurements and near-fault trilateration and levelling data. Adopting the 18-mm shortening of 1999 as a reference, the deficit in shortening reached $4 \mathrm{~mm}$ in $2000,5.5 \mathrm{~mm}$ in 2001, $4 \mathrm{~mm}$ in 2002, $3 \mathrm{~mm}$ in 2003 (22, 30.5, 22 and $16.7 \%$, respectively), thus a total of $16.5 \mathrm{~mm}$ of deficit until the 2003 Chengkung earthquake. With reference to the $22 \mathrm{~mm} \mathrm{yr}^{-1}$ average creeping rate of the 1992 1997 period, this decrease is higher (at least $18.2 \%$ in $1999,36.4 \%$ in $2000,43.2 \%$ in $2001,36.4 \%$ in 2002 and $31.8 \%$ in 2003) and the total deficit reached $46 \mathrm{~mm}$ at the end of 2003. Finally, adopting the $27 \mathrm{~mm} \mathrm{yr}^{-1}$ shortening rate of $1986-1992$, the total deficit was up to $106 \mathrm{~mm}$. We interpret this diminution in creeping rate in 2000-2003 as an evidence of strain accumulation prior to the Chengkung earthquake.

We conclude that the creepmeters installed in 1998 revealed a significant decrease in creeping rate of the Chihshang Fault during the 5.5 years preceding the 2003 Chengkung earthquake. Additional consideration of the 1990-1997 results [1,2] and other twice-ayear measurements support this conclusion and indicates major diminution in average creeping rate, from $22 \mathrm{~mm} \mathrm{yr}^{-1}$ in $1990-1997$ to $14 \mathrm{~mm} \mathrm{yr}^{-1}$ in 20002003. The deficit of 2000-2003 in surface creep is about $23 \%$ on average with reference to 1999 , and no less than $37 \%$ on average with reference to the 1990 1997 period.

The period of strain deficit was terminated by the 2003 Chengkung earthquake $(M w=6.6)$. We infer that a larger deficit would be followed by a stronger earthquake like the 1951 Yuli earthquake $(M s=7.1)$. With respect to our earlier results [1,2], the estimated minimum strain deficit at the time of the Chengkung earthquake is $46-106 \mathrm{~mm}$ (Fig. 4). Our recent measurements revealed a shortening of about $97 \mathrm{~mm}$, mainly post-seismic, from 10 December 2003 to 31 December 2004. We consequently tend to adopt the upper bound of the minimum strain deficit, $106 \mathrm{~mm}$ before the earthquake, involving about 12 years of strain accumulation. It would mean that most of the detectable deficit has been relaxed by the Chengkung earthquake sequence. Although it is difficult to draw definite conclusions with less than 18 years of accurate information, we point out that creepmeter installation and monitoring deserve consideration in such seismotectonic environments, as a useful contribution to seismic hazard mitigation. 


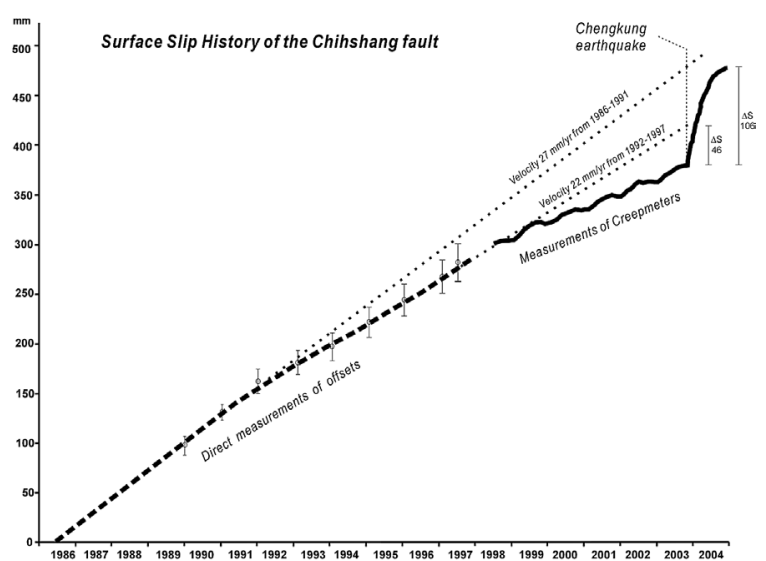

Fig. 4. Shortening across the Chihshang Fault, from mid-1986 to December 2004, with tentative estimate of strain deficit before the Chengkung earthquake (10 December 2003). Shortening (millimetres) versus time (years). Dashed line: results 1986-1997 [1,2]. Solid line: results 1998-2003, Chinyuan creepmeters. Uncertainties as error bars (for creepmeter data, within curve thickness). Dotted lines: extrapolation of aseismic creep shortening until the Chengkung earthquake: upper bound from 1986-1991, lower bound from 1992-1997, respectively giving minimum strain deficits of 106 and $46 \mathrm{~mm}$ in December 2003.

Fig. 4. Raccourcissement sur la faille de Chihshang, de la mi-1986 à décembre 2004, avec essai d'estimation du déficit de déformation avant le séisme de Chengkung (10 décembre 2003). Raccourcissement (millimètres) en fonction du temps (années). Ligne tiretée : résultats de 1986 à 1997 [1,2]. Ligne continue : résultats de 1998 à 2003, extensomètres de Chinyuan. Incertitudes indiquées par des barres d'erreur (dans l'épaisseur de la courbe pour les données des extensomètres). Lignes pointillées : extrapolation du raccourcissement par glissement asismique jusqu'au séisme de Chengkung, borne supérieure d'après 1986-1991, borne inférieure d'après 1992 à 1997 , indiquant respectivement 106 et $46 \mathrm{~mm}$ de déficit minimum de déformation en décembre 2003.

\section{Acknowledgements}

This study was conducted under the auspices of the France-Taiwan cooperation framework ('Institut français à Taipei' and National Science Council of Taiwan). Our work was supported by the Institute of Earth Sciences, Academia Sinica, and National Science Council grants NSC 91-2119-M001-027, 922116-M001-005 and 93-2116-M-001-020 on the Taiwan side, the 'Institut universitaire de France' and the CNRS (Pics Taiwan) on the French side. The generous help of Mr Guo-Jang Jiang, Mr Chang Shern-Hsiung, Mrs Mei-Chi Lu and Mr. Yin-Peng Tsao for local surveys and data collection is gratefully acknowledged.
This is a contribution of Institute of Earth Sciences, Academia Sinica, IESAS1040.

\section{References}

[1] J. Angelier, H.T. Chu, J.-C. Lee, Shear concentration in a collision zone: kinematics of the active Chihshang Fault, Longitudinal Valley, eastern Taiwan, Tectonophysics 274 (1997) 117-144.

[2] J. Angelier, H.T. Chu, J.-C. Lee, J.C. Hu, Active faulting and earthquake risk: the Chihshang Fault case, Taiwan, J. Geodyn. 29 (2000) 151-185.

[3] C.P. Chang, J. Angelier, C.Y. Huang, Origin and evolution of a melange: the active plate boundary and suture zone of the Longitudinal Valley, Taiwan, Tectonophysics 325 (2000) 4362.

[4] S.N. Cheng, Y.T. Yeh, M.S. Yu, The 1951 Taitung earthquake in Taiwan, J. Geol. Soc. China 39 (3) (1996) 267-285.

[5] H.T. Chu, J.-C. Lee, J. Angelier, Non-seismic rupture of the Tapo and the Chinyuan area on the southern segment of the Huatung Longitudinal Valley Fault, Eastern Taiwan, in: Annu. Meet. Soc. Geol. China, Taipei, 1994, pp. 1-5.

[6] C.S. Ho, A synthesis of the geologic evolution of Taiwan, Tectonophysics 125 (1986) 1-16.

[7] T.L. Hsu, The earthquakes of Taiwan, Quart. J. Bank Taiwan 7 (1955) 39-63 (in Chinese).

[8] J.-C. Lee, Structure et déformation active d'un orogène : Taiwan, Mém. Sci. Terre (1994) 94-17 \& thesis, Université Pierreet-Marie-Curie, Paris-6, 1994, 281 p.

[9] J.-C. Lee, J. Angelier, Location of active deformation and geodetic data analyses: an example of the Longitudinal Valley Fault, Taiwan, Bull. Soc. géol. France 164 (4) (1993) 533-570.

[10] J.-C. Lee, F.S. Jeng, H.T. Chu, J. Angelier, J.C. Hu, A rod-type creepmeter for measurement of displacement in active fault zone, Earth, Planets, and Space 52 (5) (2000) 321-328.

[11] J.-C. Lee, J. Angelier, H.T. Chu, J.C. Hu, F.S. Jeng, Continuous monitoring of an active fault in a plate suture zone: a creepmeter study of the Chihshang active fault, eastern Taiwan, Tectonophysics 333 (2001) 219-240.

[12] J.-C. Lee, J. Angelier, H.-T. Chu, J.-C. Hu, F.-S. Jeng, R.-J. Rau, Active fault creep variations at Chihshang, Taiwan, revealed by creepmeter monitoring, 1998-2001, J. Geophys. Res. 108 (B11) (2003) 2528; 10.1029/2003JB002394.

[13] J.-C. Savage, A dislocation model of strain accumulation and release at a subduction zone, J. Geophys. Res. 88 (1983) 49844996.

[14] Y.B. Tsai, Seismotectonics of Taiwan, Tectonophysics 125 (1986) 17-38.

[15] S.B. Yu, H.Y. Chen, L.C. Kuo, Velocity field of GPS stations in the Taiwan area, Tectonophysics 274 (1997) 41-59.

[16] S.B. Yu, L.C. Kuo, Present-day crustal motion along the Longitudinal Valley Fault, eastern Taiwan, Tectonophysics 333 (2001) 199-217.

[17] S.B. Yu, C.C. Liu, Fault creep on the central segment of the longitudinal valley fault, Eastern Taiwan, Proc. Geol. Soc. China 32 (3) (1989) 209-231. 